\title{
Pengaruh 7 Kontak Air Susu Ibu (Asi) Terhadap Pengetahuan Dan Keberhasilan Menyusui 40 Hari Ibu Post Partum Di Upt Puskesmas Wilayah Kota Cirebon Tahun 2019
}

\section{Pepi Hapitria1, Neli Nurlina2}

\author{
1,2Program Studi D.III Kebidanan Cirebon, Poltekkes Kemenkes Tasikmalaya, Provinsi Jawa Barat \\ *correspondence author: Telepon: 0231-200277, Fax: 0231-200277, \\ E-mail:hapitriapepi@gmail.com
}

DOI: $10.33859 / \mathrm{dksm} . \mathrm{v} 11 \mathrm{i} 1.618$

\begin{abstract}
Abstrak
Latar Belakang : Edukasi laktasi adalah salah satu hal penting yang harus diperhatikan saat calon ibu ingin memberikan ASI secara maksimal untuk bayinya. Penggunaan metode yang tepat akan memberikan dampak yang efektif dalam mencapai tujuan. Selama ini edukasi laktasi terdapat pada Program Kelas Ibu, namun ada alternatif lain yang dikeluarkan oelh WHO untuk mengedukasi laktasi yaitu dikenal dengan 7 kontak Air Susu Ibu (ASI).

Tujuan : Mengetahui Pengaruh 7 Kontak ASI Terhadap Pengetahuan dan Keberhasilan ASI Ekslusif 40 Hari Post Partum di UPT Puskesmas Wilayah Kota Cirebon Tahun 2019.

Metode : Desain penelitian quasi experiment dengan jumlah sampel $40 \mathrm{ibu}$ hamil, masing-masing 20 kelompok intervensi dan 20 kelompok kontrol, diambil secara purposive sampling. Uji analisis yang digunakan adalah mac nemar, chi square dan regresi logistik dengan tingkat kemaknaan $\mathrm{p}<0,05$ dan $95 \%$ CI.

Hasil : Hasil uji mc nemar menunjukkan terdapat perbedaan proporsi pengetahuan sebelum dan setelah intervensi dengan nilai $\mathrm{p}=0,016$ untuk kelompok 7 kontak ASI dan nilai $\mathrm{p}$ 0,003 untuk kelompok edukasi laktasi. Tidak terdapat hubungan antara 7 kontak ASI dengan status keberhasilan menyusui ekslusif dengan nilai $\mathrm{p}=0,32$. Namun bila dilihat dari nilai OR 2,46, artinya responden 7 kontak ASI berpeluang untuk memberikan ASI ekslusif sebanyak 2,46 kali dibandingkan responden yang mendapat edukasi laktasi. Faktor yang signifikan berpengaruh pada pengetahuan adalah pendidikan responden dengan nilai $\mathrm{p}=0,003$

Kesimpulan : Tidak terdapat pengaruh antara 7 kontak ASI dengan keberhasilan menyusui, namun 7 kontak ASI berpeluang meningkatkan pemberian ASI ekslusif. Disarankan, pemahaman 7 kontas ASI dapat disertakan dalam Program Kelas Ibu.

Kata kunci : Pengetahuan, 7 Kontak ASI, Kelas Edukasi Laktasi
\end{abstract}




\begin{abstract}
Background: Lactation education is one of the important things that must be considered when expectant mothers want to give maximum milk to their babies. The use of appropriate methods will have an effective impact in achieving goals. During this time, lactation education is at the "Program Kelas Ibu", but there is another alternative to educating that is by introducing intensive lactation counseling known as 7 contact of breast milk.

Objective: This study to analyze the effects of 7 contacts of breast milk with knowledge and success of exclusive breastfeeding 40 days post partum in UPT Puskesmas Cirebon City in 2019

Method: The design of this study was quasi-experimental. The sample size were of 40 pregnant women, 20 intervention groups and 20 control groups each, taken by purposive sampling. Technique and statistical tests use the mac namer, chi-square and logistic regression test.

Results: The results of the mc nemar test showed that there was a difference in the proportion of knowledge before and after the intervention with a value of $p=0.016$ for the group of 7 contacts of breast milk and $p$ value of 0.003 for the lactation education group. There was no relationship between 7 contacts of breast milk with the status of exclusive breastfeeding success with $p=0.32$. However, if seen from the OR value of 2.46, it means that respondents 7 contacted breast milk have the opportunity to provide exclusive breastfeeding as much as 2.46 times compared to respondents who received lactation education. A significant factor influencing knowledge is respondent education with $p=0.003$

Conclusion: There was no influence between 7 contacts of breast milk with the success of breastfeeding, but 7 contacts of breast milk have the opportunity to increase exclusive breastfeeding. It is recommended, an understanding of 7 contacts of breast milk can be included in the "Program Kelas Ibu".
\end{abstract}

Keywords: Knowledge, 7 Contacts of breast milk, Lactation Education Class

\section{Pendahuluan}

\section{Berdasarkan United Nations}

Childrens Fund (UNICEF), bahwa sebanyak 30.000 kematian bayi di Indonesia dan 10 juta kematian anak balita di dunia pada tiap tahunnya bisa dicegah melalui pemberian ASI secara eksklusif selama enam bulan sejak tanggal kelahirannya, tanpa harus memberikan makanan serta minuman tambahan kepada bayi (Roesli, 2000). Sebagai bentuk dukungan hal tersebut, maka pemerintah mengeluarkan Peraturan
Pemerintah No. 33 Tahun 2012 tentang Pemberian ASI Ekslusif.

Angka pemberian ASI ekslusif di Indonesia masih tergolong rendah. Menurut Badan Penelitian dan Pengembangan Kesehatan (2018) terdapat peningkatan proporsi pola pemberian ASI ekslusif menjadi $37,3 \%$. Angka tersebut masih jauh di bawah rekomendasi WHO sebesar 50\%. Di Jawa Barat, proporsi pola pemberian ASI ekslusif masih dibawah angka nasional yaitu $35 \%$. 
Bila melihat data cakupan ASI Ekslusif di Kota Cirebon pada Tahun 2017 61,5\% dari target capaian adalah $55 \%$, dengan demikian cakupan telah tercapai. Tahun 2019 Kota Cirebon akan meningkatkan target cakupan ASI Ekslusif menjadi $60 \%$ (Dinas Kesehatan Kota Cirebon, 2017). Ketercapaian target yang telah terlampaui bukan berarti menjadi dasar tenaga kesehatan untuk tetap memberikan pelayanan seperti yang telah berjalan, namun tetap harus meningkatkan pelayanan untuk lebih meningkatkan cakupan ASI Ekslusif. Hal ini dikarenakan beberapa wilayah masih memiliki angka cakupan yang rendah. Berdasarkan Laporan Profil Dinas Kesehatan Kota Cirebon Tahun 2017 diperoleh data bahwa besar cakupan ASI Ekslusif Tahun 2017 terendah ada di wilayah Kecamatan Pekalipan 51,25\% dan Kecamatan Kesambi 61,95\%.

Upaya yang sudah dilakukan untuk meningkatkan cakupan ASI ekslusif di Kota Cirebon salah satunya adalah dengan disahkannya Peraturan Daerah Kota Cirebon Nomor 4 Tahun 2016 tentang Inisiasi Menyusu Dini dan Pemberian ASI Ekslusif dan hal ini diharapkan menjadi landasan hukum untuk semua pihak agar mendukung pemberian ASI ekslusif (Dinkes Kota Cirebon, 2017).

Banyak faktor yang menjadi penyebab cakupan ASI yang rendah. Menurut Moeloek (2018) dalam temu media kegiatan Pekan
ASI sedunia Tahun 2018, mengungkapkan bahwa faktor penyebab hal tersebut, diantaranya adalah kurangnya pengetahuan ibu tentang manajemen laktasi. Menurut Yahmin (2015) sitasi Febriani, Kamsiah dan Marleni (2018), pengetahuan ibu tentang pentingnya pemberian ASI harusnya dimulai sedini mungkin sejak masa kehamilan, sehingga dengan adanya pengetahuan yang cukup tentang ASI dan menyusui diharapkan ibu dan keluarga sudah siap dalam menjalani proses menyusui nanti.

Faktor lain yang dapat mempengaruhi keberhasilan menyusui adalah pendidikan. Semakin tinggi tingkat pendidikan ibu semakin banyak pengetahuan ibu yang dapat mengembangkan sikap ibu terhadap keberhasilan ASI Eksklusif (Ransum, Syam dan Hendrayati, 2012). Pendidikan dapat mempengaruhi perilaku untuk memotivasi diri sehingga mampu berperan dalam pembangunan kesehatan. Semakin tinggi tingkat pendidikan seseorang, semakin mudah menerima informasi sehingga semakin banyak pengetahuan yang didapatkannya. Pendidikan yang lebih tinggi akan dapat mempengaruhi seseorang salah satunya mudah menerima gagasan, ide dan materi (Notoatmodjo, 2014)

Selain dari faktor pendidikan, pengetahuan yang baik akan dicapai bila ditunjang dengan edukasi yang tepat. Selama ini pelaksanaan edukasi laktasi telah 
termasuk dalam Program Kelas Ibu, namun hanya sebagian kecil materi tentang manajemen laktasi yang disampaikan.. Alternatif lain dengan mengenalkan konseling laktasi intensif yang kita kenal dengan 7 kontak ASI. Menurut Setiawan (2015), pelaksanaan 7 kontak ASI yang direkomendasikan oleh World Health Organization (WHO) adalah dimulai dari kehamilan trimester tiga sampai pasca persalinan dan bila ditemukan masalah menyusui diluar waktu-waktu tersebut. Menurut Febriani, Kamsiah dan Marleni (2011) menunjukkan terdapat hubungan antara pelaksanaan 7 kontak ASI dengan keberhasilan ibu menyusui ekslusif dengan $p$ value 0,000 dan OR 7,088.

Ambarwati, Muis dan Susantini (2013) menyampaikan bahwa konseling laktasi yang intensif meningkatkan jumlah ibu yang memberikan ASI ekslusif dengan nilai $p$ 0,000. Demikian pula menurut Biks, Tariku dan Tessema (2015) bahwa konseling ASI yang intensif dari awal kehamilan sampai dengan setelah persalinan berkontribusi pada praktik pemberian ASI ekslusif $\mathrm{p}<0,05$.

Selain dari metode edukasi laktasi, peran suami yang tak kalah penting dengan cara memberi dukungan. Dukungan yang diberikan oleh suami akan membantu suksesnya proses menyusui secara ekslusif oleh ibu (Wulandari, 2009). Menurut Roesli
(2000), dukungan suami sangat diperlukan agar pemberian ASI ekslusif bisa tercapai.

\section{Bahan dan Metode}

Jenis penelitian adalah quasi experimental pre and post test with control group design, dengan dua kelompok sampel yaitu kelompok intervensi ( 7 kontak ASI) dan kelompok kontrol (kelas edukasi laktasi). Kelompok intervensi, ibu hamil di wilayah UPT Puskesmas Jagasatru dan kelompok kontrol ibu hamil di wilayah UPT Puskesmas Pulasaren dengan perhitungan besar sampel menggunakan rumus dengan merujuk pada Lemeshow et al., (1990), sehingga diperoleh sampel 40, masing-masing kelompok 20 responden. Pengumpulan data pengetahuan menggunakan kuesioner dari Hapitria dan Padmawati (2017) dengan nilai cronbach's alpha 0,738, dan instrumen dukungan suami menggunakan kuesioner Wulandari (2009) nilai cronbach's alpha 0.953 . Teknik analisis data secara univariat, bivariat dengan $M c$ Namer dan Chi square, serta multivariat dengan regresi logistik 
Dinamika Kesehatan Jurnal Kebidanan dan Keperawatan Vol 11 No. 1 Juli 2020 (ISSN: 2086-3454 EISSN: 2549-4058)

url: http://ojs.dinamikakesehatan.unism.ac.id DOI : https://doi.org/10.33859/dksm.v11i1

Pengaruh 7 Kontak Air Susu Ibu (Asi) Terhadap Pengetahuan Dan Keberhasilan Menyusui 40 Hari Ibu Post Partum Di Upt Puskesmas Wilayah Kota Cirebon Tahun 2019

Hasil

Analisis univariat digunakan untuk mendeskripsikan karakteristik masingmasing variabel penelitian dengan distribusi frekuensi dan prosentase masing-masing variabel, yang dituangkan pada tabel berikut:

Tabel 1: Distrbusi Frekuensi Karakteristik Responden Pada Kelompok Intervensi dan Kontrol di UPT Puskesmas Kota Cirebon Tahun 2019

\begin{tabular}{|c|c|c|}
\hline Variabel & $\mathbf{N}$ & $\%$ \\
\hline \multicolumn{3}{|l|}{ Pengetahuan } \\
\hline \multicolumn{3}{|l|}{ Intervensi } \\
\hline Baik & 13 & 32,5 \\
\hline Kurang & 27 & 67,5 \\
\hline \multirow{2}{*}{\multicolumn{3}{|c|}{$\begin{array}{l}\text { Pengetahuan } \\
\text { Intervensi }\end{array}$}} \\
\hline & & \\
\hline Baik & 31 & 77,5 \\
\hline Kurang & 9 & 22,5 \\
\hline \multicolumn{3}{|c|}{ Keberhasilan Menyusui } \\
\hline Eksklusif & 26 & 65 \\
\hline Tidak Eksklusif & 14 & 35 \\
\hline \multicolumn{3}{|l|}{ Dukungan Suami } \\
\hline Mendukung & 10 & 25 \\
\hline Tidak Mendukung & 30 & 75 \\
\hline \multicolumn{3}{|l|}{ Pendidikan } \\
\hline Tinggi & 26 & 65 \\
\hline Rendah & 14 & 35 \\
\hline
\end{tabular}

Berdasarkan Tabel 1, terdapat peningkatan pengetahuan sebelum dan setelah intervensi sebesar $45 \%$, untuk keberhasilan menyusui dan status pendidikan mayoritas responden menyusui secara ekslusif dan berpendidikan tinggi dengan jumlah masing-masing 26 responden (65\%), dan dukungan suami mayoritas tidak mendukung sebanyak 30 responden (75\%).

Tabel 2. Analisis Mc Namer Pengetahuan Responden Pada Kelompok 7 Kontak ASI dan Edukasi
Laktasi sebelum dan setelah intervensi di UPT Puskesmas Kota Cirebon Tahun 2019

\begin{tabular}{|c|c|c|c|}
\hline \multirow[t]{3}{*}{ Pengetahuan } & \multicolumn{2}{|c|}{ Setelah Intervensi } & \multirow{3}{*}{$\begin{array}{l}\text { Nilai } \\
\text { p }\end{array}$} \\
\hline & Baik & Kurang & \\
\hline & $\mathbf{n}$ & $\%$ & \\
\hline
\end{tabular}

\begin{tabular}{lllll}
\hline 7 Kontak ASI & & & & \\
Sebelum Intervensi & & & & \\
$\quad$ - Baik & 9 & 45 & 0 & 0 \\
- Kurang & 7 & 35 & 4 & 20 \\
\hline
\end{tabular}

Edukasi Laktasi

Sebelum Intervensi

- $\begin{array}{lllll}\text { Baik } & 3 & 15 & 1 & 5\end{array}$

\begin{tabular}{llllll}
- & Kurang & 12 & 60 & 4 & 20 \\
\hline
\end{tabular}

0,016

Berdasarkan Tabel 2, untuk kelompok

7 kontak ASI diperoleh nilai p 0,016 dan nilai

p 0,003 untuk kelompok edukasi laktasi.

Artinya terdapat perbedaan proporsi

pengetahuan sebelum dan setelah intervensi

pada kedua kelompok.

Tabel 3 : Analisis Chi Square Hubungan 7 Kontak ASI terhadap Pengetahuan Responden di UPT Puskesmas Kota Cirebon Tahun2019

\begin{tabular}{llllll}
\hline \multirow{2}{*}{ Kelompok } & \multicolumn{3}{l}{ Pengetahuan } & Nilai \\
\cline { 2 - 5 } & \multicolumn{3}{l}{ Baik } & \multicolumn{3}{l}{ Kurang } & p \\
\cline { 2 - 5 } & $\mathbf{n}$ & $\mathbf{\%}$ & $\mathbf{n}$ & $\mathbf{\%}$ & \\
\hline 7 Kontak ASI & 16 & 80 & 4 & 20 & \multirow{2}{*}{0,5} \\
\hline Edukasi Laktasi & 15 & 75 & 5 & 25 & \\
\hline Total & 26 & 77,5 & 9 & 22,5 & \\
\hline
\end{tabular}

Berdasarkan Tabel 3, diperoleh nilai $p$ $=0,5$. Artinya tidak terdapat hubungan antara 7 kontak ASI dengan pengetahuan responden.

Tabel 4 : Analisis Chi Square Hubungan 7 Kontak ASI dengan Keberhasilan Menyusui di UPT Puskesmas Kota Cirebon Tahun2019

\begin{tabular}{llllll}
\hline Kelompok & \multicolumn{2}{l}{ Status Menyusui } & Nilai p \\
\cline { 2 - 5 } & \multicolumn{2}{c}{ Ekslusif } & \multicolumn{2}{c}{ Tidak } & \\
& \multicolumn{4}{c}{ Ekslusif } & \\
\cline { 2 - 5 } & n & \% & n & \% & \\
\hline 7 Kontak ASI & 11 & 55 & 9 & 44 & 0,32 \\
\hline Edukasi Laktasi & 15 & 75 & 5 & 25 & \\
\hline Total & 26 & 65 & 14 & 35 &
\end{tabular}

Berdasarkan Tabel 4, diperoleh nilai $\mathrm{p}=0,32$.

Artinya tidak terdapat hubungan antara 7 
kontak ASI dengan status keberhasilan menyusui ekslusif.

Tabel 5 : Analisis Chi Square Variabel Luar Terhadap Pengetahuan Responden UPT Puskesmas Kota Cirebon Tahun 2019

\begin{tabular}{|c|c|c|c|c|c|}
\hline \multirow[t]{3}{*}{ Kelompok } & \multicolumn{4}{|c|}{ Pengetahuan } & \multirow{3}{*}{$\begin{array}{l}\text { Nilai } \\
\mathbf{p}\end{array}$} \\
\hline & \multicolumn{2}{|c|}{ Baik } & \multicolumn{2}{|c|}{ Kurang } & \\
\hline & $\mathbf{n}$ & $\%$ & n & $\%$ & \\
\hline \multicolumn{6}{|l|}{ Pendidikan } \\
\hline Tinggi & 23 & 88,5 & 3 & 11,5 & 0,03 \\
\hline Rendah & 15 & 75 & 5 & 25 & \\
\hline \multicolumn{6}{|l|}{ Dukungan } \\
\hline Suami & & & & & 0,6 \\
\hline $\mathrm{Ya}$ & 8 & 80 & 2 & 20 & \\
\hline Tidak & 23 & 76,7 & 7 & 23,3 & \\
\hline
\end{tabular}

Berdasarkan Tabel 5, pendidikan diperoleh nilai $\mathrm{p}=0,033$ dan nilai $\mathrm{p}=0,6$ untuk dukungan suami. Artinya terdapat hubungan antara pendidikan dan pengetahuan, namun tidak terdapat hubungan antara dukungan suami dengan pengetahuan responden.

Tabel 6 : Analisis Chi Square Variabel Luar Terhadap Keberhasilan Menyusui di UPT Puskesmas Kota Cirebon Tahun 2019

\begin{tabular}{|c|c|c|c|c|c|}
\hline \multirow[t]{3}{*}{ Kelompok } & \multicolumn{4}{|c|}{$\begin{array}{l}\text { Keberhasilam } \\
\text { Menyusui }\end{array}$} & \multirow[t]{3}{*}{$\begin{array}{l}\text { Nilai } \\
\mathbf{p}\end{array}$} \\
\hline & \multicolumn{2}{|c|}{ Ekslusif } & \multicolumn{2}{|c|}{$\begin{array}{l}\text { Tidak } \\
\text { Ekslusif }\end{array}$} & \\
\hline & $\mathbf{n}$ & $\%$ & $\mathbf{n}$ & $\%$ & \\
\hline \multicolumn{6}{|l|}{ Pendidikan } \\
\hline Tinggi & 16 & 61,5 & 10 & 38,5 & 0,39 \\
\hline Rendah & 10 & 71,4 & 4 & 28,6 & \\
\hline
\end{tabular}

\begin{tabular}{clllll}
\hline $\begin{array}{c}\text { Dukungan Suami } \\
\text { Ya }\end{array}$ & & & & & \\
Tidak & 6 & 60 & 4 & 40 & 0,49 \\
& 20 & 66,7 & 10 & 33,3 & \\
\hline
\end{tabular}

Berdasarkan Tabel 6, diperoleh nilai $\mathrm{p}=0,39$ untuk pendidikan. Artinya tidak terdapat hubungan antara pendidikan dengan keberhasilan menyusui. Dukungan suami diperoleh nilai $\mathrm{p}=0,49$. Artinya tidak terdapat hubungan antara dukungan suami dengan keberhasilan menyusui.

Pendidikan merupakan variabel luar yang memenuhi syarat untuk masuk ke uji analisis multivariat dikarenakan nilai $\mathrm{p}<$ 0,25. Namun setelah dilakukan pengujian variabel pengganggu, pendidikan merupakan variabel pengganggu karena selisih nilai OR lebih dari $10 \%$, namun memiliki presisi kurang baik sehingga model yang dipilih adalah sebagai berikut :

Tabel 7 : Analisis Multivariat Regresi Logistik Pendidikan Terhadap Pengetahuan Responden di UPT Puskesmas Kota Cirebon Tahun 2019

\begin{tabular}{llllll}
\hline Variabel & $\begin{array}{l}\text { Koefi } \\
\text { sien }\end{array}$ & S.E & $\begin{array}{l}\text { Nilai } \\
\mathbf{p}\end{array}$ & OR & $\begin{array}{l}\text { CI 95 } \\
\text { \% }\end{array}$ \\
\hline $7 \quad$ Kontak & 0,288 & 0,761 & 0,705 & 1,33 & $0,3-$ \\
$\begin{array}{l}\text { ASI } \\
\text { Konstanta }\end{array}$ & $-1,386$ & 0,559 & 0,013 & 0,25 & 5,9 \\
\end{tabular}

Berdasarkan analisis multivariat regresi logistik pada Tabel 7 , diperoleh nilai p > 0.05, artinya 7 kontak ASI secara statistik tidak berhubungan terhadap keberhasilan menyusui. Namun bila dilihat dari nilai OR 1,33 , dapat diartikan bahwa responden yang mendapat edukasi laktasi berpeluang untuk memiliki pengetahuan kurang sebesar 1,33 kali dibandingkan dengan responden yang mendapat 7 kontak ASI.

Hubungan variabel luar (dukungan suami dan pendidikan ibu) terhadap keberhasilam menyusui menunjukkan bahwa kedua faktor tersebut tidak memenuhi syarat untuk masuk 
ke uji analisis multivariat $(\mathrm{p}>0,25)$. Namun secara klinik dukungan berpengaruh terhadap variabel dependen sehingga dimasukan ke pemodelan. Namun setelah dilakukan pengujian variabel confounding, dukungan suami bukan termasuk variabel counfounding karena selisih nilai OR kurang dari $10 \%$, maka model yang dipilih adalah sebagai berikut:

Tabel 8 : Analisis Multivariat Regresi Logistik Dukungan Suami dengan Keberhasilan Menyusui 40 Hari Post Partum di UPT Puskesmas Kota Cirebon Tahun 2019

\begin{tabular}{lllllll}
\hline & $\begin{array}{l}\text { Koefi } \\
\text { sien }\end{array}$ & S.E & $\begin{array}{l}\text { Nila } \\
\text { i p }\end{array}$ & OR & $\begin{array}{l}\text { CI } \\
\text { \% }\end{array}$ & 95 \\
\hline 7 Kontak ASI & 0.901 & 0.68 & 0.18 & 2.46 & 0.6 & -9.4 \\
Konstanta & -1.099 & 0.51 & 0.03 & 0.33 & - & \\
\hline
\end{tabular}

Berdasarkan analisis multivariat regresi logistik pada Tabel 8, diperoleh nilai $\mathrm{p}>0.05$, artinya 7 kontak ASI secara statistik tidak berhubungan terhadap keberhasilan menyusui. Namun bila dilihat dari nilai OR 2,46 , dapat diartikan bahwa responden yang mendapat 7 kontak ASI berpeluang untuk memberikan ASI ekslusif sebanyak 2,46 kali dibandingkan dengan responden yang mendapat edukasi laktasi.

\section{PEMBAHASAN}

Karakteristik yang dilihat dalam penelitian pada Tabel 1 adalah pengetahuan, keberhasilan menyusui, dukungan suami dan pendidikan responden. Karakteristik pengetahuan menunjukkan bahwa responden yang terlibat dalam penelitian sebelum dilakukan intervensi sebagian besar memiliki pengetahuan kurang 27 orang $(67,5 \%)$, sedangkan setelah dilakukan intervensi mengalami peningkatan pengetahuan menjadi baik sebanyak 31 orang $(77,5 \%)$. Karakteristik keberhasilan menyusui dan status pendidikan mayoritas responden menyusui secara ekslusif dan berpendidikan tinggi

dengan jumlah masing-masing 26 responden (65\%), dan dukungan suami sebagian besar responden tidak mendapat dukungan saat proses menyusui yaitu sebanyak 30 orang (75\%).

Faktor peningkatan pengetahuan dalam suatu edukasi dapat terjadi karena konselor yang baik. Menurut Azwar (2003) dalam Rosidi (2018), untuk menjamin keberhasilan suatu konseling perlu konselor yang baik, ditunjang dengan pengetahuan, ketrampilan dan kemampuan konselor dalam mengemukakan sesuatu dan bisa memberikan inspirasi bagi ibu dengan edukasi tersebut. Sehingga akan berdampak terhadap keberhasilan dalam penerimaan informasi sehingga pengetahuan pun akan meningkat (Suksesty et al., 2016)

Berdasarkan Tabel 2, untuk kelompok 7 kontak ASI diperoleh nilai $p$ 0,016 dan nilai p 0,003 untuk kelompok edukasi laktasi. Artinya dari kedua metode edukasi yang dilakukan terdapat perbedaan proporsi pengetahuan sebelum dan setelah intervensi. Adanya pemberian informasi 
melalui kedua metode intervensi, maka apabila dilihat dari pengetahuan ke dua kelompok menunjukkan memiliki pengaruh yang berarti dalam meningkatkan pengetahuan. Informasi atau pengetahuan yang sering dan berulang-ulang dapat meningkatkan retensi pengetahuan seseorang (Notoatmodjo, 2014). Namun penelitian ini berbeda dengan Ambarwati, Muis dan Susantini (2013) yang menunjukkan pengetahuan kelompok yang mendapat konseling laktasi yang intensif lebih tinggi dibanding kelompok kontrol. Hal ini dapat terjadi dikarenakan konseling laktasi yang intensif menempatkan ibu sebagai subyek bukan sebagai obyek.

Kelompok responden dalam penelitian ini mendapatkan edukasi mengenai laktasi dengan metode yang berbeda, yaitu dengan 7 kontak ASI dan edukasi laktasi. Berdasarkan Tabel 4 yaitu untuk mengetahui hubungan 7 kontak ASI dengan keberhasilan menyusui diperoleh nilai $p=0,32$. Nilai $p>$ 0,05 maka dapat disimpulkan tidak terdapat hubungan antara 7 kontak ASI dengan status keberhasilan menyusui ASI ekslusif 40 hari post partum. Hasil tersebut menunjukkan bahwa 7 kontak ASI bukan merupakan metode yang paling efektif terhadap keberhasilan menyusui.

Ada beberapa faktor yang dapat mempengaruhi keberhasilan menyusui yang tidak diteliti pada saat ini, diantaranya adalah faktor pengalaman ibu yang dapat mempengaruhi perilaku ibu dalam memenuhi kebutuhan bayi terutama pemberian ASI secara ekslusif.

Hasil penelitian ini tidak sejalan dengan Notoatmodjo (2014) yaitu semakin banyak ibu mendapatkan konseling dari petugas kesehatan atau peer konselor yang telah dilatih konseling menyusui, maka semakin mudah bagi ibu untuk mempertahankan menyusui.

Hal ini kemungkinan bisa terjadi karena pada saat kunjungan rumah masih ada ibu yang merasa khawatir akan kemampuannya memberikan ASI pada bayinya. Masih ada perasaan dalam diri ibu, merasa ASI nya tidak cukup untuk memenuhi kebutuhan nutrisi bayinya sehingga memberikan susu formul, ini disebut syndrom ASI. Kondisi syndrom ASI kurang dapat mempengaruhi keberhasilan menyusui ekslusif (Roesli, 2000).

Menurut Dennis (2003) sitasi Wardani, (2012) faktor lain yg memungkinkan untuk tidak berhasilnya ASI Ekslusif adalah masih adanya peran tenaga kesehatan dalam mempromosikan susu formula, serta dukungan keluarga yang kurang karena sebagian besar responden masih tinggal dengan ibu dan atau mertua. Keadaan fisiologis dan psikologis merupakan faktor yang berpengaruh pada keberhasilan menyusui. Seseorang biasanya tidak akan 
merasa aman, nyaman, dan yakin dapat menyelesaikan suatu proses jika selama menjalani proses tersebut ia merasa tertekan secara emosional dan membuatnya tidak nyaman untuk melakukan apapun.

Berdasarkan analisis regresi logistik yang dapat dilihat pada Tabel 7 dan 8 menunjukkan bahwa meskipun secara statistik 7 kontak ASI tidak berpengaruh terhadap pengetahuan dan keberhasilan menyusui namun ibu yang mendapatkan 7 kontak ASI akan memiliki peluang 2,4 kali untuk dapat memberikan ASI nya secara eksklusif dibandingkan dengan yang hanya diberikan edukasi laktasi saja. Begitupun ibu yang mendapatkan hanya edukasi laktasi saja akan memiliki peluang 1,3 kali untuk memiliki pengetahuan yang kurang tentang laktasi.

Berdasarkan hal tersebut maka dapat disimpulkan bahwa pengetahuan dan keberhasilan menyusui tidak dipengaruhi oleh kuantitas dari edukasi, tetapi sangat dipengaruhi oleh kualitas dari edukasi. Selain itu kualitas dari konselor sangat mempengaruhi pengetahuan dan kepercayaan ibu dalam menyusui.
7 kontak ASI dan edukasi laktasi merupakan metode edukasi yang sama-sama efektif terhadap peningkatan pengetahuan dan keberhasilan ASI Eksklusif 40 hari Post Partum

\section{Daftar Pustaka}

Ambarwati, R., Muis, S. F. and Susantini, P. (2013) 'Pengaruh Konseling Laktasi Intensif Terhadap Pemberian Air Susu Ibu ( ASI ) Eksklusif Sampai 3 Bulan', JUrnal Gizi Indonesia, 2(1), pp. 16-23.

Badan Penelitian dan Pengembangan Kesehatan (2018) Hasil Utama RISKESDAS 2018. Jakarta.

Biks, G. A., Tariku, A. and Tessema, G. A. (2015) 'Effects of Antenatal Care and Institutional Delivery on Exclusive Breastfeeding Practice in Northwest Ethiopia: A Nested Case - Control Study', International Breastfeeding Journal. International Breastfeeding Journal, pp. 1-6. doi: 10.1186/s13006-015-0055-4.

Dinas Kesehatan Kota Cirebon (2017) Profil Dinas Kesehatan Kota Cirebon Tahun 2017. Cirebon.

Dinkes Kota Cirebon (2017) Profil Kesehatan Tahun 2016. Kota Cirebon: Pemda Kota Cirebon.

Febriani, A., Kamsiah and Marleni, W. A. (2018) 'Pelaksanaan 7 kontak ASI pada Keberhasilan Menyusui', Jurnal Medika Kesehatan, 11(1), pp. 7-11.

\section{SIMPULAN}

Hapitria, P. and Padmawati, R. (2017) 'Efektifitas Pendidikan Kesehatan Melalui Multi Media dan Tatap Muka 
Dinamika Kesehatan Jurnal Kebidanan dan Keperawatan Vol 11 No. 1 Juli 2020 (ISSN: 2086-3454 EISSN: 2549-4058)

url: http://ojs.dinamikakesehatan.unism.ac.id DOI : https://doi.org/10.33859/dksm.v11i1

Pengaruh 7 Kontak Air Susu Ibu (Asi) Terhadap Pengetahuan Dan Keberhasilan Menyusui 40 Hari Ibu Post Partum Di Upt Puskesmas Wilayah Kota Cirebon Tahun 2019

terhadap Pengetahuan dan Sikap Ibu Hamil Tentang ASI dan Menyusui di Wilayah UPTD Puskesmas Sitopeng Kota Cirebon Tahun 2018', Jurnal Ilmiah Ilmu Kesehatan Care, 5(2), p. 156.

Lemeshow, S. et al. (1990) Adequacy of Sample Size in Health Studies. New York, Brisbane, Toronto, Singapore: John Wiley \& Sons Ltd.

Notoatmodjo, S. (2014) Ilmu Perilaku Kesehatan. Jakarta: Rineka Cipta.

Ransum, U., Syam, A. and Hendrayati (2012) Hubungan Sikap Ibu, Pendidikan dan Dukungan Peetugas Kesehatan dengan Pemberian ASI Ekslusif pada Bayi Umur 6-11 Bulan di Puskesmas Antang Perumnas Kota Mmakasar. Universitas Hasanuddin.

Roesli, U. (2000) Mengenal ASI Ekslusif. 1st edn. Jakarta: Trubus Agriwidya.

Rosidi, D. Y. I. (2018) Pengaruh Edukasi Konselor Laktasi dengan Menggunakan Kartu Kendali Edukasi dan Lembar Balik Terhadap Keberhasilan Menyusui Influence. Universitas Hasanuddin Makasar.

Suksesty, C. E. et al. (2016) 'Peran Konseling Laktasi dengan Penerapan Media terhadap Tingkat Keyakinan Diri dan Keberhasilan Menyusui pada Ibu Post partum', IJEMC, 3(2), p. 48.

Wardani, M. A. (2012) Gambaran Tingkat Self-Efficacy untuk Menyusui pada Ibu Primigravida. Universitas Indonesia.

Wulandari, D. E. (2009) Peran Ayah pada Kepatuhan Ibu dalam Pemberian ASI Ekslusif diWilayah Kerja Puskesmas

Tegalrejo Kota Yogyakarta.
Universitas Gadjah Mada.

